\title{
APRENDIZAGEM ORGANIZACIONAL E GESTÃO DO CONHECIMENTO: UM DESAFIO A SER ENFRENTADO
}

\author{
Isabel Amélia Costa Mendes ${ }^{1}$
}

Ter plena compreensão das pessoas como ativos, identificando e explorando suas diversidades intrínsecas para adicionar valor aos projetos e resultados organizacionais, é um desafio a ser enfrentado se quisermos monitorar com competência o potencial e a contribuição que os recursos intangíveis podem oferecer para o sucesso das organizações.

Dentre os fatores que procedem à maximização dos recursos humanos, a aprendizagem organizacional e a administração do conhecimento se destacam como imprescindíveis para o nosso tempo.

O conhecimento explícito e o conhecimento tácito interpõem-se nas organizações. Enquanto que o conhecimento explícito, formal e sistemático, é facilmente disseminado fornecendo informações rápidas e confiáveis, de acesso disponibilizável e conectando pessoas para sua utilização, o conhecimento tácito provém de experiência pessoal, intuição, bom senso e insights sendo, portanto, muito mais difícil de ser comunicado. As soluções e conselhos criativos que podem advir desse tipo de conhecimento tornam necessário seu compartilhamento, e aqui o diálogo é um importante mecanismo de aprendizagem.

A administração do conhecimento contempla "maneiras deliberadas e sistemáticas para criar, captar, organizar e transferir conhecimento"(1). Três forças impulsionam esta gestão: 1) a tecnologia da informação favorecendo a disseminação compartilhada do conhecimento explícito e propiciando a conexão das pessoas em redes para o intercâmbio e compartilhamento do conhecimento tácito; 2) o capital intelectual se tornou o alicerce da economia. Desta forma, os dirigentes passam a investir e utilizar os recursos de conhecimento; 3) o interesse na gestão do conhecimento se vincula intimamente aos empenhos das organizações de se transformarem em organizações de aprendizagem ${ }^{(1)}$.

$\mathrm{Na}$ área da saúde, a enfermagem em suas distintas práticas tem reconhecido as pessoas - prestadoras e recebedoras do cuidado - como seus ativos mais importantes. Em seu contexto, é inegável a contribuição que os conceitos da aprendizagem organizacional e gestão do conhecimento podem oferecer para a qualidade da assistência e da gerência desenvolvidas.

Assim, mecanismos para sustentar a coleta e o compartilhamento do conhecimento explícito e tácito devem se integrar na pauta das ações dos enfermeiros.

\section{REFERÊNCIA BIBLIOGRÁFICA}

1. Daft RL. Organizações: teorias e projetos. São Paulo: Pioneira Thompson Learning; 2002.

\footnotetext{
${ }^{1}$ Editor da Revista Latino-Americana de Enfermagem, Diretor, Professor Titular da Escola de Enfermagem de Ribeirão Preto, da Universidade de São Paulo, Centro Colaborador da OMS para o desenvolvimento da pesquisa em enfermagem, e-mail: iamendes@eerp.usp.br
} 


\title{
ORGANIZATIONAL LEARNING AND KNOWLEDGE MANAGEMENT: A CHALLENGE WE MUST FACE
}

\author{
Isabel Amélia Costa Mendes ${ }^{1}$
}

To fully comprehend people as assets, identifying and exploring their intrinsic diversities in order to add value to organizational projects and results is a challenge that must be faced if we aim at monitoring with competence the potential and contribution that the intangible resources may offer to the success of the organizations.

Among the factors that result in the maximization of human resources, the organizational learning and knowledge management are the ones that are emphasized as fundamental to our times.

The explicit and tacit knowledge are part of the organizations. While the explicit, formal and systematic knowledge is easily disseminated, supplying quick and trustable information and connecting people to use it, the tacit knowledge is a consequence of personal experiences, intuition and insights and, therefore, it is more difficult to communicate. The creative solutions and advises that may result from this kind of knowledge need to be shared and the dialogue, in this context, is the most important learning tool.

Knowledge management contemplates "deliberate and systematic ways of creating, organizing and transferring knowledge" ${ }^{(1)}$. There are three forces that stimulate this type of management: 1) the information technology favoring the shared dissemination of explicit knowledge, enabling the connection of people in networks to exchange and share tacit knowledge; 2) the intellectual capital is the basis of economy. Therefore, the leaders are investing and using knowledge resources; 3 ) the interest in knowledge management is linked to the organization's efforts to transform them in learning organizations $^{(1)}$.

In the health area, nursing and its different practices are recognizing people - who provide and receive the care - as their most important assets. In this context, it is incontestable the contribution of the concepts linked to organizational learning and knowledge management to the quality and administration of the care.

Thus, the mechanisms to enable the collection and sharing of explicit and tacit knowledge must integrate the agenda of nurses' actions.

\section{REFERENCES}

1. Daft RL. Organizações: teorias e projetos. São Paulo: Pioneira Thompson Learning; 2002.

\footnotetext{
${ }^{1}$ Editor of "Revista Latino-Americana de Enfermagem", Dean, Full Professor of the University of São Paulo at Ribeirão Preto College of Nursing - WHO Collaborating Centre for Nursing Research Development, e-mail: iamendes@eerp.usp.br
} 


\title{
APRENDIZAJE ORGANIZACIONAL Y GESTIÓN DEL CONOCIMIENTO: UN DESAFIÓ A SER ENFRENTADO
}

\author{
Isabel Amélia Costa Mendes ${ }^{1}$
}

Tener plena comprensión de las personas como activos, identificando y explorando sus diversidades intrínsecas para adicionar valor a los proyectos y resultados organizacionales, es un desafió que debemos enfrentar si queremos monitorizar con competencial el potencial y la contribución que los recursos intangibles pueden ofrecer para el éxito de las organizaciones.

Dentro de los factores que contribuyen con la maximización de los recursos humanos, el aprendizaje organizacional y la administración del conocimiento se destacan como los imprescindibles para nuestro tiempo.

El conocimiento explicito y el conocimiento tácito se entrecruzan en las organizaciones. Mientras que el conocimiento explicito, formal y sistemático se disemina fácilmente ofreciendo informaciones rápidas y confiables, de acceso disponible y conectando personas para su utilización, el conocimiento tácito proviene de la experiencia personal, intuición, buen sentido, por lo tanto, se comunica más fácilmente.

Las soluciones y consejos creativos que pueden venir de ese tipo de conocimiento hacen que sea necesario compartirlos, aquí el dialogo es un importante mecanismo de aprendizaje.

La administración del conocimiento contempla "maneras deliberadas y sistemáticas para crear, captar, organizar y transferir conocimiento"(1). Tres fuerzas impulsan esta gestión: 1) la tecnología de la información favoreciendo la diseminación compartida del conocimiento explicito y propiciando la conexión de las personas en redes para el intercambio del conocimiento tácito; 2) el capital intelectual se tornó el apoyo de la economía. De esta forma, los dirigentes pasan a invertir y utilizar los recursos del conocimiento; 3 ) el interés en la gestión del conocimiento se vincula íntimamente con los empeños de las organizaciones para transformarse en organizaciones de aprendizaje.(1)

En el área de la salud, la enfermería en sus distintas prácticas ha reconocido las personas - prestadoras y recibidoras de cuidado - como sus activos más importantes. En su contexto, es innegable la contribución que los conceptos del aprendizaje organizacional y la gestión del conocimiento pueden ofrecer para la calidad de la atención y de la gerencia desarrollada.

Así, mecanismos para sustentar la recolección y el intercambio de conocimiento explícito y tácito se deben integrar en la pauta de las acciones de los enfermeros.

\section{REFERÊNCIA BIBLIOGRÁFICA}

1. Daft RL. Organizações: teorias e projetos. São Paulo: Pioneira Thompson Learning; 2002.

\footnotetext{
${ }^{1}$ Editora de la "Revista Latino-Americana de Enfermagem", Director, Profesor Titular de la Escuela de Enfermería de Ribeirão Preto, de la Universidad de São Paulo, Centro Colaborador de la OMS para el desarrollo de la investigación en enfermería, correo electrónico: iamendes@eerp.usp.br
} 